J. Clin. Chem. Clin. Biochem.

Vol. 25, 1987, pp. 87-90

(C) 1987 Walter de Gruyter \& Co.

Berlin · New York

\title{
Solid-Phase Antigen Immunoassay for the Detection of Anti-Zona Pellucida-Antibodies in Clinically Defined Sera
}

\author{
By $A . B$. Czuppon
}

Biotec-International, Hannover, F.R.G.

\section{J. Dietl $\left.{ }^{1}\right)$}

Abteilung Frauenheilkunde und MICHAELIS-Hebammenschule der Universität Kiel, Kiel, F.R.G. and

\section{Tripatzis}

Institut für Monoklonale Antikörper, Hannover, F.R.G.

(Received March 7/September 30, 1986)

Summary: A new solid-phase antigen immunoassay was developed for the detection of anti-zona pellucidaantibodies. The assay was validated in a double blind study with clinically defined sera. The new assay is easy to perform and large numbers of sera can be processed in one day. The antigen can be prepared in advance and stored until use. This represents an advantage over other methods, such as immunofluorescence and RIA, which require fresh antigen preparation for each set of assays. With this new test ca. $7 \%$ of females and ca. $20 \%$ of males with unexplained infertility have shown elevated antibody concentrations compared with fertile controls. The estimated intra-assay and inter-assay CV were $8.5 \%$ and less than $10 \%$ respectively.

\section{Introduction}

The zona pellucida is an extracellular glycoprotein matrix surrounding the mammalian oocyte (1). Because of the known immunological cross-reactivity between the human and the porcine zona pellucida $(2,3)$ various studies were undertaken in order to detect anti-zona pellucida-antibodies in sera of infertile women (4-6). Recently Sacco et al. (3) and Trounson et al. (7) have shown that the in vitro fertilization of human oocytes can be completely blocked by antiporcine-zona pellucida-antibodies. Furthermore it was reported that the sera of infertile women contain auto-antibodies against the zona pellucida which could be an important parameter for the cause of infertility $(5,8-12)$. In spite of these findings the exact role of autoantibodies remains questionable because they have also been found in

1) Present adress: Universitätsfrauenklinik Tübingen, 7400 Tübingen, F.R.G. sera of fertile women $(4,6)$. In addition these antizona pellucida-antibodies have also been found in sera of fertile men $(4,13)$.

These conflicting results might be due to the use of different antigen preparations and detection methods. A standardized method seems to be needed for the detection of anti-zona pellucida-antibodies in order to compare results from different laboratories. This would be an additional diagnostic aid for immunologically caused infertility. In the present work a defined antigen preparation (14) was used which was obtained by solubilization of porcine zona pellucida with lithium $3^{\prime}, 5^{\prime}$-diiodosalicylate $(15,16)$. It was anticipated that by using defined zona pellucida-antigens, undesirable nonspecific reactions could be eliminated. Clinically defined sera from the WHO-reference sera bank (Aarhus, Denmark), have been tested in a double blind study by the newly developed solidphase antigen immunoassay. 


\section{Materials and Methods}

\section{Isolation of zonae pellucidae}

The method of Gwatkin et al. (17) was used for the large scale isolation of approximately 50000 porcine zonae. Briefly the procedure was as follows: the whole ovaries were minced, digested with collagenase (Sigma Chem. Co. Deisenhofen, FRG) and filtered through nylon screens of various pore sizes. Following the last filtration through a $75 \mu \mathrm{m}$ screen, the residue was suspended in $0.05 \mathrm{~mol} / \mathrm{l}$ phosphate buffer, $\mathrm{pH} 7.3$ in 0.15 $\mathrm{mol} / \mathrm{l} \mathrm{NaCl}$ and checked for purity under the microscope.

\section{Solubilization of zonae pellucidae}

The solubilization procedure was basically that described by Dietl et al. (16). The 50000 zonae were suspended in $1 \mathrm{ml}$ of $0.3 \mathrm{~mol} / 1$ lithium $3^{\prime}, 5^{\prime}$-diiodosalicylate in $0.05 \mathrm{~mol} / 1 \mathrm{Tris} / \mathrm{HCl}$ buffer, $\mathrm{pH} 7.5$. The suspension was stirred for $15 \mathrm{~min}$ at room temperature, and an equal volume of distilled water was added. The diluted mixture was then incubated for an additional 10 min and centrifuged at $45000 \mathrm{~g}$ for $90 \mathrm{~min}$ at $4{ }^{\circ} \mathrm{C}$. The sediment was discarded and the supernatant mixed with a $50 \mathrm{~g} / \mathrm{l}$ phenol/ water solution at a volume ratio of $1: 1$, to eliminate any possible contamination by protein. The suspension was then stirred for another $50 \mathrm{~min}$ at $4^{\circ} \mathrm{C}$, centrifuged at $4000 \mathrm{~g}$ for 60 $\min \left(4^{\circ} \mathrm{C}\right)$ and the aqueous phase separated. The latter was then dialysed for $48 \mathrm{~h}$ against several changes of bi-distilled water at $4^{\circ} \mathrm{C}$. The dialysate was lyophilized and the glycoproteins were precipitated in absolute ethanol. The precipitate was then collected by centrifugation at $4000 \mathrm{~g}$ for $60 \mathrm{~min}$ at $4{ }^{\circ} \mathrm{C}$ and dissolved $1 \mathrm{ml}$ of $0.05 \mathrm{~mol} / \mathrm{l}$ buffer in $0.15 \mathrm{~mol} / 1 \mathrm{NaCl}, \mathrm{pH}$ 7.3 .

\section{Preparation of the antigen-coated solid-phase}

The procedure was basically the same as described previously for the detection of antisperm antibodies (18). The solubilized antigens were incubated with nylon beads (Paesel, $3 \mathrm{~mm}$ diameter) at $90 \mathrm{mg}$ protein per 60 beads per $\mathrm{ml}$, with gentle shaking for $120 \mathrm{~min}$ at room temperature. This was followed by an overnight incubation at $4{ }^{\circ} \mathrm{C}$. The beads were then washed in ice-cold $0.05 \mathrm{~mol} / 1$ phosphate buffer $\mathrm{pH} 7.8$, dried and stored at $4^{\circ} \mathrm{C}$ until use. The same antigen mixture was used for several batches of new coatings, since only a fraction of the antigen is bound to the nylon surface at this protein concentration.

\section{Preparation of the radiolabelled tracer}

Protein-A, which preferentially binds to the Fc portions of antibodies (mainly to IgG's and IgM), was used as a tracer (18). The labelling with ${ }^{125}$ I was carried out as described previously (19). The specific activity was calculated at $259 \mathrm{kBq} / \mu \mathrm{g}$.

\section{Solid-phase antigen immunoassay}

The patient sera were diluted $1: 100$ with the above buffer and $200 \mu$ l were pipetted into separate RIA tubes, each containing an antigen-coated bead. The beads were incubated for $60 \mathrm{~min}$ at $37^{\circ} \mathrm{C}$ and washed three times with $0.05 \mathrm{~mol} / 1$ phosphate buffer in $0.15 \mathrm{~mol} / 1 \mathrm{NaCl}$, containing $1 \%$ (by vol.) Tween-20. Following the last wash, $200 \mu \mathrm{l}$ of the radio-labelled tracer $(1.72 \mathrm{kBq})$ was pipetted into each tube and these were incubated and washed again as described above. After the last wash the beads were transferred to new tubes and counted in a gamma counter for $1 \mathrm{~min}$ each. The bound anti-zona pellucida-anti- body concentrations in the sera of patients were calculated (19 a) according to the equation

$\mathrm{ng} \mathrm{IgG}=\frac{\text { average counts } / \mathrm{min} \times \mathrm{BC}}{1290 \times \mathrm{SA}}$

where

$\mathrm{BC}=$ binding capacity of ${ }^{125} \mathrm{I}$-protein- $\mathrm{A}$ in $\mathrm{ng} / \mathrm{ng}$

1290 (counts $/ \mathrm{min}$ ) $/ \mathrm{nCi}=$ constant

$\mathrm{SA}=$ specific activity of the ${ }^{125} \mathrm{I}$-protein-A in $\mathrm{nCi} / \mathrm{ng}$

All assays were carried out in triplicate.

\section{Test sera}

The sera were sent to the laboratory frozen, on dry ice, from the WHO Reference Bank for Reproductive Immunology, Aarhus, Denmark. All sera were thawed once just prior to the assays. The double blind study was coordinated by Dr. Hjort under the trial number of 77180 and included sera of clinically defined categories as follows (number of sera in parenthesis):

Females: fertile (20), post-partum (15), post-menopausal (7), primary amenorrhoe (2), virgin (12), pregnant (37), recurrent abortion (13), unexplained infertile (84).

Males: fertile (16), congenital absence of vas (3), aspermatogenesis (5), vasectomy (15), unexplained infertile (83).

Among the coded sera there were also 30 matched pairs with randomly distributed sample numbers. These sera were used for the estimation of reproducibility.

\section{Quality control}

In order to maintain an adequate quality control, a positive control serum, rabbit anti-porcine-zona pellucida-anti-serum, (6) with known titre, was aliquoted, frozen at $-70^{\circ} \mathrm{C}$ and thawed only once to be included with each set of assays. This procedure ensured that both the test sera and the positive control serum were frozen and thawed only once. The intraassay and inter-assay $\mathrm{CV}$ were estimated.

\section{Sperm-agglutination and sperm-immobilization} tests

The sperm-agglutination and sperm-immobilization test where carried out according to the method of Friberg (21) and Husted \& Hjort (22).

\section{Results}

\section{Females}

The normal range of anti-zona pellucida-antibody concentrations, based on the results of the fertile ${ }^{*}$ groups, was estimated to be $0.1-1.47 \mu \mathrm{g} / \mathrm{l} \mathrm{IgG}$.

The sera of six out of 84 female patients (ca. 7\%) with unexplained infertility showed an elevated autoantibody concentration compared with fertile controls. A Box \& Whisker plot of the results indicates a higher median for the infertile group and elevated anti-zona pellucida-antibody concentrations in six cases compared with the fertile group (fig. 1). In addition, one out of 13 patients with recurrent abor- 

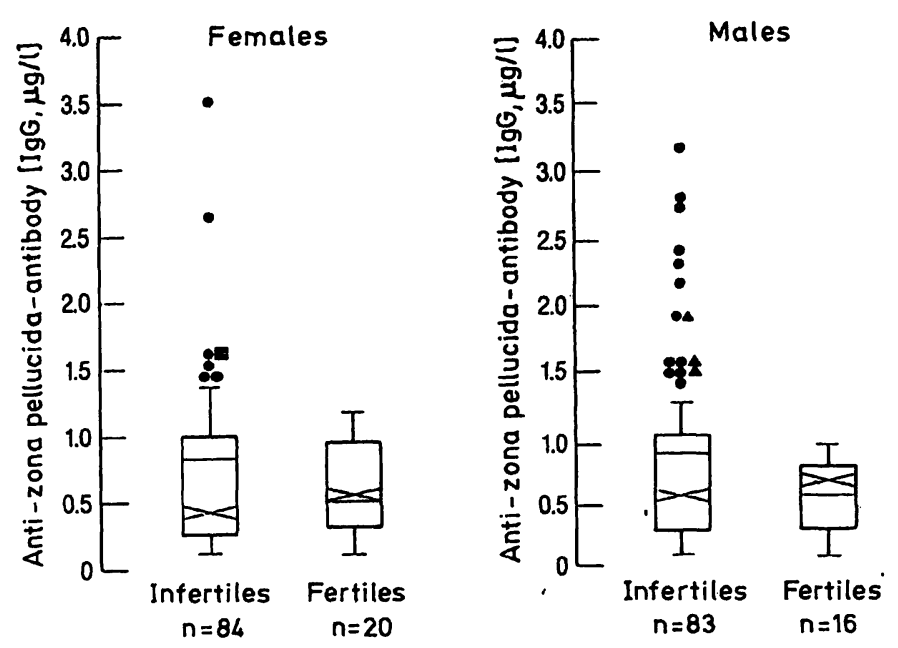

Fig. 1. Box \& Whisker distributions plots of the anti-zona pellucida-antibody levels in the clinically defined sera from the WHO.

The $25 \%$ and $75 \%$ interquartile distances are drawn as boxes.

Median: (-),

arithmetic mean: $(\longrightarrow)$,

$\mathrm{n}$ : number of patents.

The extreme values are plotted individually.

a recurrent abortion

$\Delta$ vasectomy

tion also showed increased antibody concentration. The values of all other clinical categories were within the normal range of fertiles (tab. $1 \mathrm{a}$ ). In all cases the conventional agglutination and immobilization tests failed to detect the presence of antisperm-antibodies. The clinical history revealed that the highest level of auto-antibody concentration was present in the serum of a patient with a secondary infertility of 2 years duration. In general five out of the six positive sera were secondary infertility cases of between 2 to 10 years duration. No correlation between length of infertility and auto-antibody concentration was observed. The one patient with primary infertility had failed to conceive for six years.

\section{Males}

The normal range of antibody concentration in the fertile male group was estimated at $0.1-1.1 \mu \mathrm{g} / \mathrm{IgG}$. Using the Box-Whisker plot (fig. 1), 12 cases in the unexplained infertile groups show a higher median and increased antibody concentrations compared with the fertile controls. Three out of the 15 patients were in the vasectomized category. Other patients, with either aspermatogenesis or congenital absence of vas, showed antibody levels similar to those of the fertiles (tab. $1 \mathrm{~b}$ ). The sperm agglutination and immobilization test were negative in all cases.
Tab. 1. $a=$ Distribution of elevated anti-zona pellucida-antibody concentration in the various clinical categories of female patients.

\begin{tabular}{lll}
\hline Clinical category & Females \\
\cline { 2 - 3 } & $\begin{array}{l}\text { Number } \\
\text { of sera }\end{array}$ & $\begin{array}{l}\text { Number of cases of } \\
\text { elevated antibody } \\
\text { concentration in the } \\
\text { different categories }\end{array}$ \\
\hline Unexplained infertile & 84 & 6 \\
Recurrent abortion & 13 & 1 \\
Post-menopausal & 7 & 0 \\
Post-partum & 15 & 0 \\
Primary amenorrhoe & 2 & 0 \\
Pregnant & 37 & 0 \\
Virgin & 12 & 0 \\
\hline
\end{tabular}

Tab. 1. $b=$ Distribution of elevated anti-zona pellucida-antibody concentration in the various clinical categories of male patients.

\begin{tabular}{lll}
\hline Clinical category & Males \\
\cline { 2 - 3 } & $\begin{array}{l}\text { Number } \\
\text { of sera }\end{array}$ & $\begin{array}{l}\text { Number of cases of } \\
\text { elevated antibody } \\
\text { concentration in the } \\
\text { different categories }\end{array}$ \\
\hline Unexplained infertile & 83 & 12 \\
Vasectomy & 15 & 3 \\
Aspermatogenesis & 5 & 0 \\
Congenital absence of vas & 3 & 0 \\
\hline
\end{tabular}

The day to day variation of the assay with the positive control serum was less than $10 \% \mathrm{C}$. V. and the average intra-assay C.V. was calculated at $8.5 \%$. The positive control serum, rabbit anti-porcine-zona pellucida-anti-serum, showed an average binding of 3.95 $\pm 0.29 \mu \mathrm{g} / \mathrm{lgG}(\mathrm{n}=10)$.

\section{Discussion}

The results of this study with clinically defined sera suggest that anti-zona pellucida-antibodies could be the cause of unexplained infertility in both males and females in some cases. This is in agreement with the results of other investigators $(5,8,10)$.

In earlier studies Shivers \& Dunbar (23) have shown that $32 \%$ of infertile woman had elevated antibodyconcentrations against porcine zona pellucida. They concluded that some cases of unexplained infertility could result from auto-antibodies. Similar auto-antibodies in sera of infertile patients have been described by Mori et al. (5). In the male patients (infertile and vasectomized) this could possibly be explained by the common ontogenic origin of the germ cells as primordial germ cells in both females and males. 
These authors used different detection methods, which would be difficult to adapt for routine diagnosis.

Defining an exact "cut off" level based on parametric statistics is difficult since biological data are not normally distributed. The common practice of using the range of normal values in a negative control group (in this case, fertiles) could be adopted (in analogy to assays for tumour markers), provided that each laboratory establishes its own normal values, with clinically defined sera.

\section{References}

1. Dietl, J. (1986) Naturwissenschaften $73,89-94$.

2. Sacco, A. G. (1970) Biol. Reprod. 16, 164-174.

3. Sacco, A. G., Yurewicz, E. C., Subramanian, M. G. \& De Mayo, F. J. (1981) Biol. Reprod. 25, 997-1008.

4. Sacco, A. G. \& Moghissi, K. S. (1979) Fertil. Steril. 31, $503-505$.

5. Mori, T., Nishimoto, T., Kohda, H., Taki, J., Nishimura, T. \& Oikawa, T. (1979) Fertil. Steril. 31, 67-72.

6. Dietl, J., Knop, G. \& Mettler, L. (1982) J. Reprod. Immunol. 4, 123-131.

7. Trounson, A. O., Shivers, C. A., Mc Master, R. \& Lopata, A. (1980) Arch. Androl. 4, 29-36.

8. Nishimoto, T., Mori, T., Yamada, J. \& Nishimura, T. (1980) Fertil. Steril. 34, 552-556.

9. Candle, M. R., Scott, J. R. \& Shivers, C. A. (1982) Am. J. Reprod. Immunol. 2, 188.

10. Bousquet, D., St. Jacques, S., Roberts, K. D., Chapdelaine, A. \& Blean, G. (1982) Am. J. Reprod. Immunol. 2, 73-78.

11. Rote, N. S., Candle, M. R., Urry, R. L. \& Scott, J. R. (1983) J. Reprod. Immunol. Suppl. 5, 52-55.
So far, however, there are no reliable assays for the detection of such antibodies. Most of these assays are difficult to perform on a routine basis in the sterility clinics. Our results indicate that the new solid-phase antigen assay could be used routinely as an additional aid for the detection of anti-zona pellucida-antibodies as an immunólogical cause of infertility.

\section{Acknowledgement}

The authors wish to thank Susanne Mangold for her excellent technical assistance.

12. Singh, J. \& Mhaskar, A. M. (1985) J. Immunol. Meth. 79 , $133-142$.

13. Kurachi, H., Wakimoto, H., Sakumoto, T., Aono, T. \& Kurachi, K. (1984) Fertil. Steril. 41, 265-269.

14. Dietl, J. \& Czuppon, A. B. (1984) Gamete Res. 9, 45-54.

15. Czuppon, A. B. \& Dietl, J. (1985) Biochem. Int. 11, 21 - 34.

16. Dietl, J., Czuppon, A. B., Weichert, K. \& Mettler, L. (1983) Hoppe-Seyler's Z. Physiol. Chem. 364, 261-267.

17. Gwatkin, R. B. L., Andersen, O. F. \& Williams, D. T. (1980) Gamete Res. 3, 217-231.

18. Czuppon, A. B. (1985) J. Reprod. Immunol. 8, 313-319.

19. Czuppon, A. B. \& Mettler, L. (1983) J. Clin. Chem. Clin. Biochem. 21, 357-362.

19a. Czuppon, A. B. (1985) J. Reprod. Immunol. 8, 313-319.

20. Czuppon, A. B. (1984) Fresenius Z. Anal. Chem. 317, $728-729$.

21. Friberg, J. A. (1974) Acta Obstet. Gynec. Scand. 36, 21-26.

22. Hustedt, S. \& Hjort, T. (1975) Int. J. Fertil. 20, 97-101.

23. Shivers, C. A. \& Dunbar, B. S. (1977) Science 197, $1082-1190$
Dr. A. B. Czuppon

Biotec-International

Karmarschstraße 33

D-3000 Hannover 1 